\title{
Estimate of the Fluid Force Related to Washing Mechanism 1 Measurement of the Drag of Fine Wires on a Plate Caused by the Flow of Aqueous Solutions of Surfactant and Dilute Aqueous Solution of Polymer
}

\author{
Keiko Amaki*1, Tomiichi Hasegawa*2, and Masaaki Konno*2 \\ *1 Faculty of Education, Iwate University, \\ Ueda Morioka, Iwate, 020 Japan \\ *2 Faculty of Engineering, Department of Mechanical and Production Engineering, \\ Niigata University, Ikarashi Niigata 950-21 Japan
}

The effect of fluid force on detergency has been experimentally investigated. More than one hundred wires of $50 \mu \mathrm{m}$ in diameter, as a model of two dimensional soil, were set so as to adhere to a bottom flat plate of a two dimensional channel. The aqueous solution of surfactant and the dilute aqueous solution of polymer were made to flow through the channel and the pressure drop caused by the wires was measured. The drag and the drag coefficient $\left(C_{D}\right)$ of one wire were estimated with the pressure drop by the use of the law of momentum. The following results are obtained. For all solutions used, the drag increases and the drag coefficient decreases with an increase in the Reynolds number based on the wire diameter taken as the characteristic reference length. The solution of LAS, one of familiar anionic surfactants, gives $C_{\mathrm{D}}$ values lower than the pure water, and the difference becomes marked as the concentration of the solution increases. A nonionic surfactant solution, AE 1.0\%, shows a time dependent character; it provides about half of the coresponding $C_{\mathrm{D}}$ value of water within a day since the solution was produced, while it gives nearly the same as that of water after 4 days have passed. The $C_{\mathrm{D}}$ for dilute solution of polymer (PEO $20 \mathrm{ppm}$ ) in water is higher than those for water and surfactant solutions. Viscosities of the solutions tested were Newtonian and the magnitudes are in the same order for all three solutions. These results suggest that the variation of $C_{\mathrm{D}}$ observed for the three solutions is not directly related to the solution viscosity but probably to other properties such as elastic force.

Key words: Detergency / Drag / Fine wire / Surfactant solution/Dilute polymer solution

\section{洗浄機構に関る流体力の検討，第 1 報；壁面に付着した微小円 柱に対する界面活性剤水溶液および希薄高分子水溶液の抗力}

$$
\text { 天 木 桂 子*1 } \cdot \text { 長谷川富 市*2 } \text { 近 野 正 昭*2 }
$$

（原稿受理：1992年 6 月 8 日）

1. 緒言

洗濯洗浄に打政污れの除去機構を考光る場合, 化学的洗浄作

*1 岩手大学教育学部 $\bar{T} 020$ 盛岡市上田 $3-18--33$

*2 新潟大学工学部 $\bar{\top} 950-21$ 新潟市五十嵐 2 の町 8050
用と物理的洗浄作用の 2 点からアプローチ寸る必要がある. 化学 的作用は, 主に市販洗剤酒合されている界面活性剤によっても たらされるもので, 浸透·分散・乳化・可溶化・ローリングアッ プなどが挙げられる。これらに関してはあらゆる観点から多くの 研究が行われ, ある程度の解明が進んでいる。 
一方, 物理的作用は, 布地や污れに対して与えられる機械力に よる作用である。これ関しても, これまでいくつかの研究が行 われてきた。例えば, 洗浄液中での布地の折り曲げや摩擦, 衝突の 効果 ${ }^{1) ~ 3)}$, 遠心力や流体力を利用した固体粒子除去の検討 ${ }^{4) ~ 8), ~}$ 液流の洗浄作用の解析 ${ }^{9 \sim 12)}$, 機珹力と布の損傷との関(係 ${ }^{13) ~ 15)}$ どが挙げられる.また, 物理的作用の寄与率は, 全洗浄力の $40 〜$ 50\%を占めるという報告もある ${ }^{16)}$.

しかし，機械作用の主要因である洗浄液の流動については現時 点で不明な点が多い。 また, 流体の粘弾性が污れの除去過程にお いて果たす役割もいまだに明らかにされていない。

本研究は, 流体力の洗浄機構に対する効果を実験的理論的に解 明することを目的とする，特に本報告では, 壁面上の層流境界層 内に存在する污れモデルとして 2 次元流路の底面上に微小円柱を 付着させ, これに数種の溶液の層流せん断流を直角に当てること により生ずる圧力損失を測定し, 運動量の法則から微小円柱 1 本 当りの抗力を算出して溶液種類の違いによる影響を検討する.

\section{2. 実 験}

\section{$2 \cdot 1$ 使用流体}

界面活性剤水溶液として, 陰イオン系のリニア型ラウリルベン ゼンスルホン酸ナトリウム (LAS, 試薬 1 級, ナカライテスク), および非イオン系のポリオキシェチレンラウリルエーテル（AE， 試薬 1 級, 和光純薬ブリジ35）を重量濃度 $0.2 \%$ 1.0\%に調製し て用いた．いずれも市販の洗濯用合成洗剤に配合さ神ている一般 的なものである.

比較対象として，ポリエチンンオキサイド（製鉄化学工業 PEO 18）の重量濃度 $20 \mathrm{ppm}$ 水溶液を作り, 希薄高分子水溶液として 用いた。 この時, あらかじめ $100 \mathrm{ppm}$ の水質安定剤（明成化学 社サンデックスC）を溶解させた。

さらに代表的なニュートン流体である水（イオン交換水）を用 い, これは他の溶液の溶媒としても使用した. 水は採取直後多量 の空気を含んで扣り，そのまま実験を行うと装置内に気泡が生じ ることが考号れるため，24時間以上経過したものを用いた．

\section{$2 \cdot 2$ 実験装置}

実験の概要は, Fig. 1 に示すように, 縦横比の大きい矩形流 路の下面に張られたワイヤーの抗力を, 上流下流間の圧力差から 知るものである。すなわち, ワイヤーを含む長さ $L$ の区間で生じ た圧力損失 $P$ と， ワイヤーのない同一長さ $L$ の区間で生じた圧力 損失 $P_{0}$ の差 $\left(P-P_{0}\right)$ を， ワイ゚ーによって生じた厌力損失々 考えた.ささに，この圧力損失を，後述するようにワイヤーの抗

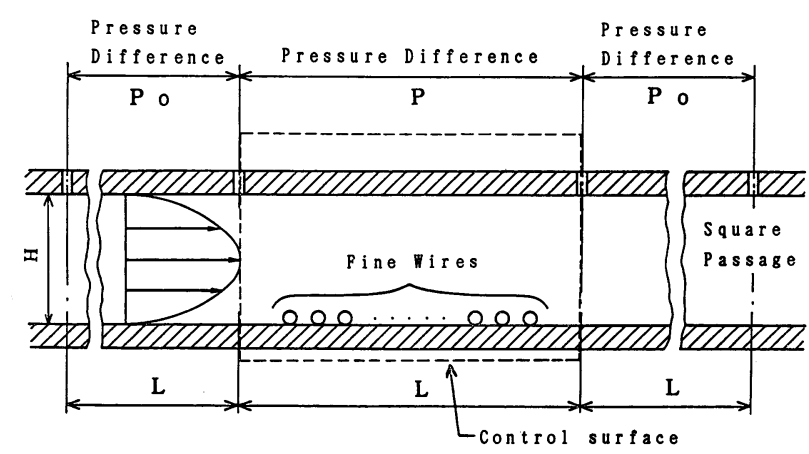

Fig. 1 Schematic explanation of experiment.

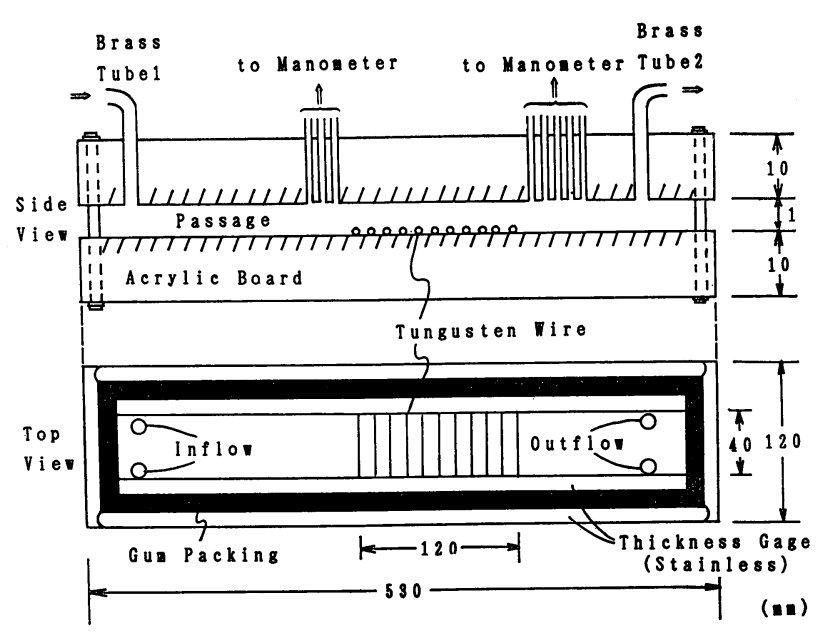

Fig. 2 Schematic representation of experimental apparatus.

\section{カに関係づけた。}

Fig. 2 に実験装置の概略を示す. 幅 $40 \mathrm{~mm}$, 高さ $1 \mathrm{~mm}$ の矩 形断面を持つ流路は, 厚さ $1 \mathrm{~mm}$ のステンレス製シックネスゲー ジを長さ $530 \mathrm{~mm}$ の透明アクリル板 2 枚で挾むことにより構成さ れている. 重ねた上下 2 枚のアクリル枚のまわりをボルトで止め, その内側にゴムパッキングを挾んで溶液のもれを防いでいる.

上下の相対位置決定打よび流路幅の確保は，4 本のステンレス 製ピンによってなされている. 流路上面となるアクリル板には, 両端から $55 \mathrm{~mm}$ の所にしんちゅ5管が 4 本立っている. 溶液流 入口であるしんちゅう管1はへッドタンクに接続されており，乙 んちゅ5管 2 は流出口である. しんちゅ5管 2 にはビニールチュ 一ブが取り付けられ, 途中のピンチュックの開閉により流量調節 を行う。また，途中 8 か所に開けられた $0.3 \mathrm{~mm}$ の圧力検出孔は， ビニールチューブを介してマノメーターと接続されている. 流路 下面のアクリル板には, しんちゅう管 1 より $200 \mathrm{~mm}$ の所から $1 \mathrm{~mm}$ 間隔で $\phi 50 \mu \mathrm{m}$ のタングステンワイヤーが 121 本張られて いる.

この装置で溶液は, しんちゅ5管 1 から装置内に流れ込み, 上 流側圧力検出孔, ワイヤー部分, 下流側圧力検出孔を通過し, 乙 んちゅ万管 2 より流出する。 この場合, 流路高さを代表長さ, 流 路内平均速度を代表速度にとったレイノルズ数 $(R e)$ は約 1,000 で, 理論上求められる層流助走区間は $123.8 \mathrm{~mm}$, また, 流路高 さ $1 \mathrm{~mm}$ に対し幅 $40 \mathrm{~mm}$ は十分広いため, 流路内の流れは 2 次 元ポアズイユ流を仮定する.

\section{$2 \cdot 3$ 測定方法}

ヘッドタンクに溶液を約 $100 l$ 入れ，溶液を流しながら装置内 部の気泡を抜いた後実験を開始した。流量調節は, 流出側のビニ ールチューブに取り付けたピンチュックの開閉により行った.

差圧の測定は, 流量調節後 10 分程経過しマノメータの水頭が一 定になった時点で行った，同時に流量 $Q$ を重量法により測定した.

\section{$2 \cdot 4$ 抗力の算出方法}

Fig. 2 亿示す 8 本の圧力検出孔の5ち, 上流側から数えて 3 -4 間のマノメータの水柱差は, ワイヤー 121 本を含む区間距離 $140 \mathrm{~mm}$ 間に生ずる圧力損失を, 他のマノメータの水柱差は, 区間距離 $10 \mathrm{~mm}$ 間に生ずる圧力損失を示す。

本実験では，ワィヤーを含む区間 $3-4$ で生じた圧力損失から， 
ワイヤーのない他の 6 区間で生じた圧力損失の平均を，区間 3 4 と同じ距離 $140 \mathrm{~mm}$ に換算して引いた值をワイヤーによって生 じた圧力損失と考劣，これをんとした．

いま，運動量の法則を適用するために，圧力検出孔 $3 ， 4$ の位 置を上流下流側境界とし，ワイヤー設置区間を含む検査体積をと り，その検查体積の表面 (検查面 (Control surface)) をFig. 1 中に示すように点線で表す。ワイヤー径 $(50 \mu \mathrm{m})$ は流路高さ $(1 \mathrm{~mm})$ 亿比較し十分小さく, かつ上流下流側検査面はワイヤ一設 置区間より $10 \mathrm{~mm}$ ずつ離れているので，速度分布は上流下流側 検查面で同一で二次元ポアズイユ流れのそれと等しいとみなして よい，従って，流体の有する運動量は検査面の入口（上流）側と 出口(下流)側で変化せず，運動量の法則から，ワイヤー設置によ る圧力損失に流路断面積をかけた力とワイヤー抗力とがつり合う ことになる。このことから次の式(1)を得る。

$$
A \rho g h=n D
$$

ここに, $A$ は流路断面積, $\rho$ は溶液の密度, $n$ はワイヤーの本 数, Dはワイヤー 1 本の抗力である.

本実験で仮定している 2 次元ポアズイユ流の速度分布は，2 次 曲線で表される．実験により測定した流量 $Q$ から次の式(2)を用い てワイヤー中心部（壁面から $25 \mu \mathrm{m}$ の地点）での流速 $V$ を求め, これを代表流速として次の式(3)からワイヤー中心部に怙けるレイ ノルズ数 $\left(R e_{\mathrm{w}}\right)$ を算出した.

$$
\begin{aligned}
& V=\frac{6 Q}{H b}\left\{\frac{y}{H}-\left(\frac{y}{H}\right)^{2}\right\} \\
& R e_{\mathrm{w}}=V d / \nu
\end{aligned}
$$

ここに，Hは流路高さ，yは壁面からワイヤー中心部までの距 離 $(=25 \mu \mathrm{m}), d$ はワイヤー直径, $b$ は流路幅, レは動粘度であ る.

さらに, 式(1)で得られた抗力 $D$ は, 抗力係数を $C_{\mathrm{D}}$ として次の 式(4)により無次元化した.

$$
D=1 / 2 C_{\mathrm{D}} \rho V^{2} S
$$

ここに，Sはワイヤーの投影面積である.

\section{3. 結果および考察}

\section{$3 \cdot 1$ ワイヤーの抗力}

Fig. 3 に,式(1)により算出したワイヤー1本分の抗力 $(D)$ と流 路内の平均レイノルズ数 $(R e)$ の関係を, 水, LAS $1.0 \%, \mathrm{PEO}$ $20 \mathrm{ppm}$ について示す．Re の小さい領域では測定誤差が大きくな り実験值はばらついている。しかし，すべての溶液でDはRe の 上年とともに増加していることがわかる. 本実験の場合, $R e=$ 100 １000で， $D=10^{-5} N \sim 10^{-4} N$ のオーダーである.

溶液別に $D$ の值をみると，高分子である $\mathrm{PEO}$ が最も高く，次 いで水，LAS の順である. 特に PEO は, 20ppm といらわずか な添加によっても水の 2 〜倍と非常に高い抗力を示している. 一方, LAS は水よりるやや低い $D$ を与光, $\mathrm{PEO}$ とは逆の挙動を 示している.

\section{$3 \cdot 2$ 抗力係数}

Fig. 4 に, 式(4)を用いて算出した水の抗力係数 $\left(C_{\mathrm{D}}\right)$ と，ワ イヤー中心部でのレイノルズ数 $\left(R e_{\mathrm{w}}\right)$ の関係を示す. 全体的に, $C_{\mathrm{D}}$ は $R e_{\mathrm{w}}$ で比較的よく整理され，右下がりの傾向を有する.

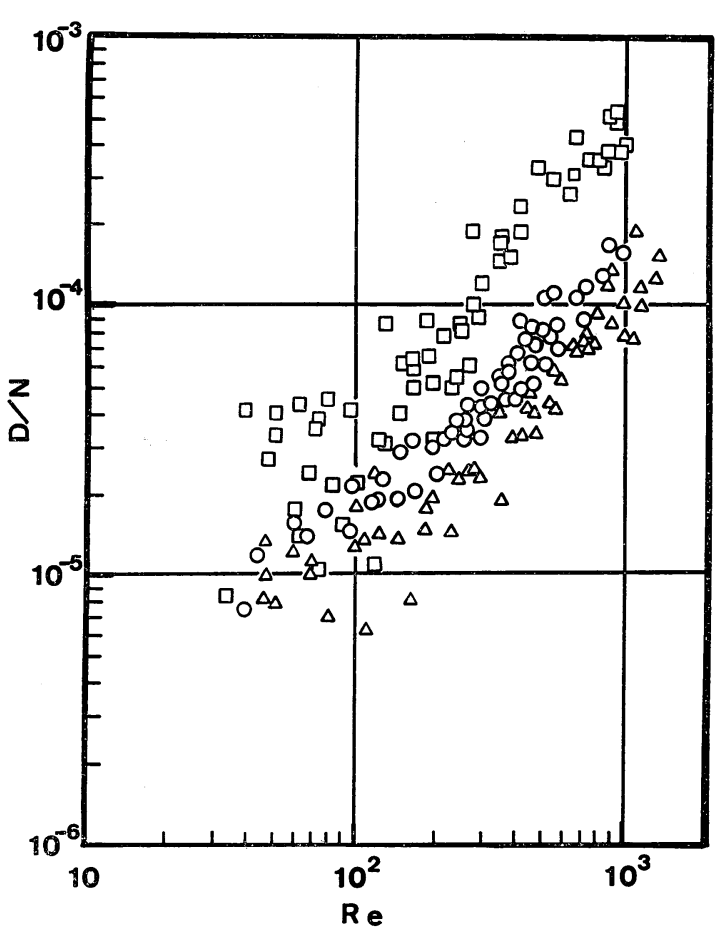

Fig. 3 Drags of one wire. O; water, $\triangle$; LAS $1.0 \%, \square$; PEO 20ppm

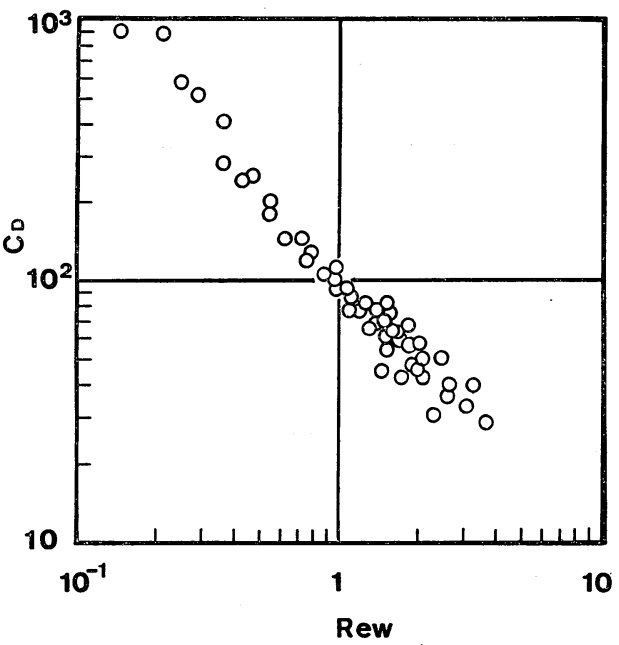

Fig. 4 Drag coefficients for water.

しかし，その下がり方は， $R e_{\mathrm{w}}=1$ 以上で鈍化する傾向がある.

Fig. 5 飞, LAS $0.2 \%, 0.5 \%, 1.0 \%$ 水溶液の $C_{\mathrm{D}}$ を示す. 図中の斜線は水の值を表している. LAS の $C_{\mathrm{D}}$ は, 水之同栐に $R e_{\mathrm{w}}$ の增加と共に右下がりの傾向を有するが，溶液濃度により異 なって招り，Re $R \geq 1$ の領域で明らかなように，本実験範囲では 濃度が高いほど低い值をとっている。すなわち，0.2\%，0.5\%は， 水とほぼ同じかやや低い， $C_{\mathrm{D}}$ を示すのに対し，1.0\% は水より明 らかに低い值を示す。このことから, 濃度が高い LAS 水溶液は, 水とは異なった流れをしていることが予想される。

Fig. 6 は, $\mathrm{AE} 1.0 \%$ の $C_{\mathrm{D}}$ を, 溶液作成後の経過時間別に示 したものであり，時間経過に伴って $C_{\mathrm{D}}$ が全体的に上界している ことがわかる。すすなわ，作成後 1 日めは $C_{\mathrm{D}}$ が最も低く，4 日 


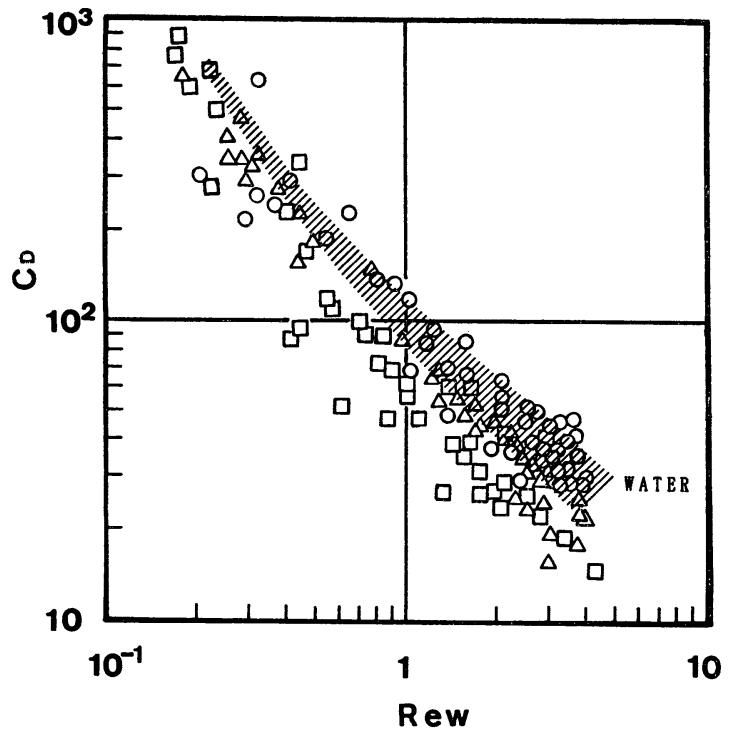

Fig. 5 Drag coefficients for LAS solutions. $\bigcirc ; 0.2 \%, \triangle ; 0.5 \%, \square ; 1.0 \%$

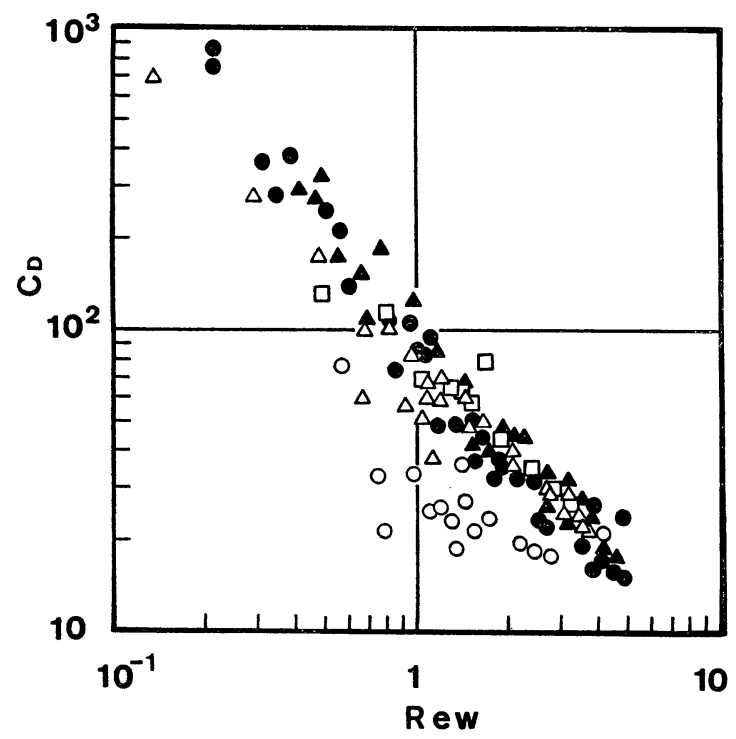

Fig. 6 Drag coefficients for AE 1.0\% solution with the time passage after producing the solution.

$\bigcirc$; 1 day, $\triangle$; 3days, $\square$; 4days, $\bullet$; 2weeks,

$\boldsymbol{\Delta} ;$ 1month

めまでは時間経過と共に高くなる傾向がみられる．しかし， 2 週 間後, 1 か月後は比較的值が安定し上升はみられない，このこと から， $\mathrm{AE}$ は溶液作成後の初期段階は性質が安定せず, 複雑な挙 動を示すことがわかる。な招，この時間経過の影響は，もう一つ の界面活性剤 LAS では見られなかった。

Fig. 7 亿，希薄高分子溶液 $\mathrm{PEO} の C_{\mathrm{D}}$ を示す，実験值はかな りばらついているが，界面活性剤水溶液とは異なり， $R e_{\mathrm{w}}>1.0$ の範囲で水より高い值を示している.

このよ5に，いずれる水より分子量の大きい溶質の水溶液が, その種類により異なった挙動を示すのは興味梁い。しかも界面活 性剤水溶液と希薄高分子溶液は， $C_{\mathrm{D}}$ について全く逆の傾向を示 している.

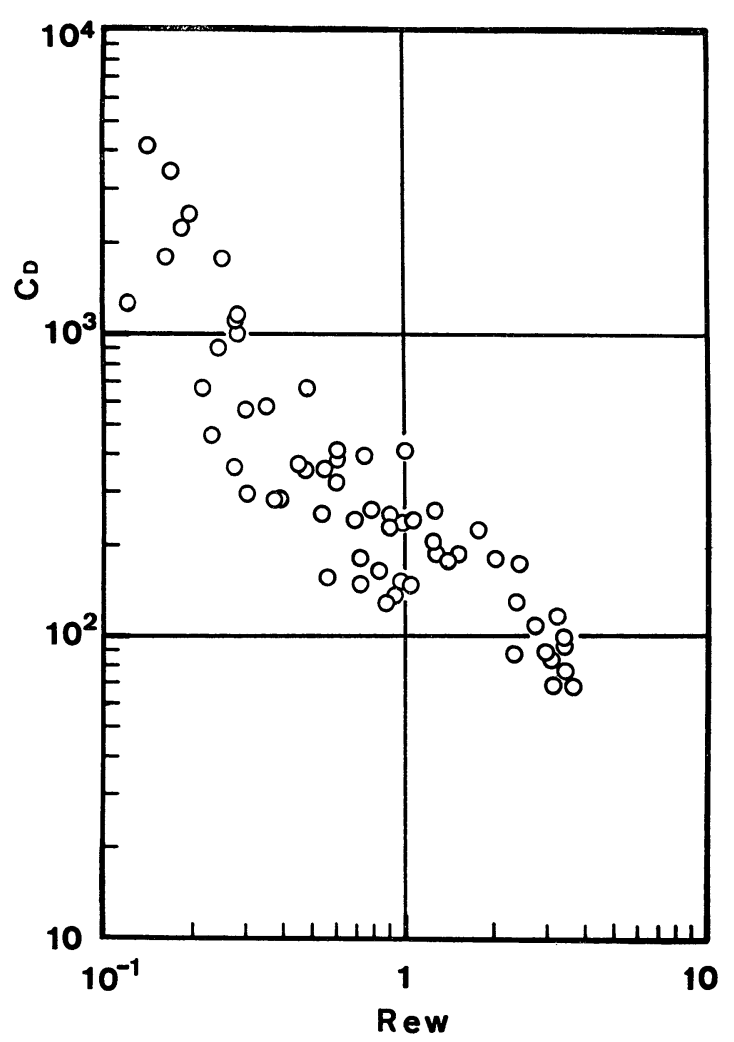

Fig. 7 Drag Coefficients for PEO 20ppm solution.

今回用いた高分子 $\mathrm{PEO}$ は分子量が数 100 万で，水溶液中では 細長いひも状で存在していると考光られている。一方, 界面活性 剤は分子量は300〜400であるが，臨界ミセル濃度 $(\mathrm{cmc})$ 以上の 水溶液中では球状ミセルを形成するため， 1 個の分子量（ミセル 量）は1万以上にも及ぶとされている。したがって，界面活性剤 水溶液は水と希薄高分子溶液の中間的性質を有すると当初予想さ れた。しかし，今回の結果は LAS や $\mathrm{AE} の C_{\mathrm{D}}$ が水上り低い 場合があり，予想とは異なる内容である。

\section{$3 \cdot 3$ 溶液の粘性}

ここで，使用した溶液の粘性を考学る。壁面せん断応力 $\left(\tau_{\mathrm{w}}\right)$ と, 壁面ずり速度 $\left(\dot{\gamma}_{\mathrm{w}}\right)$ の関係は, ニュートン粘性を有する流体 について次の式(5)で与兄られる。 また， $\tau_{\mathrm{w}}, \dot{\gamma}_{\mathrm{w}}$ は，測定可能な 量によってそれぞれ次の式(6)，式(7)で与えられる。

$$
\begin{aligned}
& \tau_{\mathrm{w}}=\mu \dot{\gamma}_{\mathrm{w}} \\
& \tau_{\mathrm{w}}=\Delta P H / 2 L \\
& \dot{\gamma}_{\mathrm{w}}=6 V_{\mathrm{a}} / H
\end{aligned}
$$

ここで, $\mu$ は粘度, $L$ は区間距離, $V_{\mathrm{a}}$ は流路内平均流速であ る.

以上の式を用いて, 水特よび界面活性剤水溶液, 希薄高分子溶 液の $\tau_{\mathrm{w}}, \dot{\gamma}_{\mathrm{w}}$ を, 前述のワイヤーのない区間の圧力損失 $(\Delta P)$ か ら算出した. 水, LAS, PEO の結果を Fig. 8 と示す. (AE に ついては戝に示してないが, LAS 1\% と注同じ值である。 また， Fig. 6 で示された $\mathrm{AE}$ の時間依存性は粘度には見られなかった。 この理由として, Fig. 8 で見るように, もともと界面活性剤の添 加による粘度増加は小さく, 仮に粘度に刘する時間経過の影響が あったとしても, 感知できない可能性のあること, また, 時間経 過の影響は, 粘度測定時のせん断流のような単純な流動場では表 


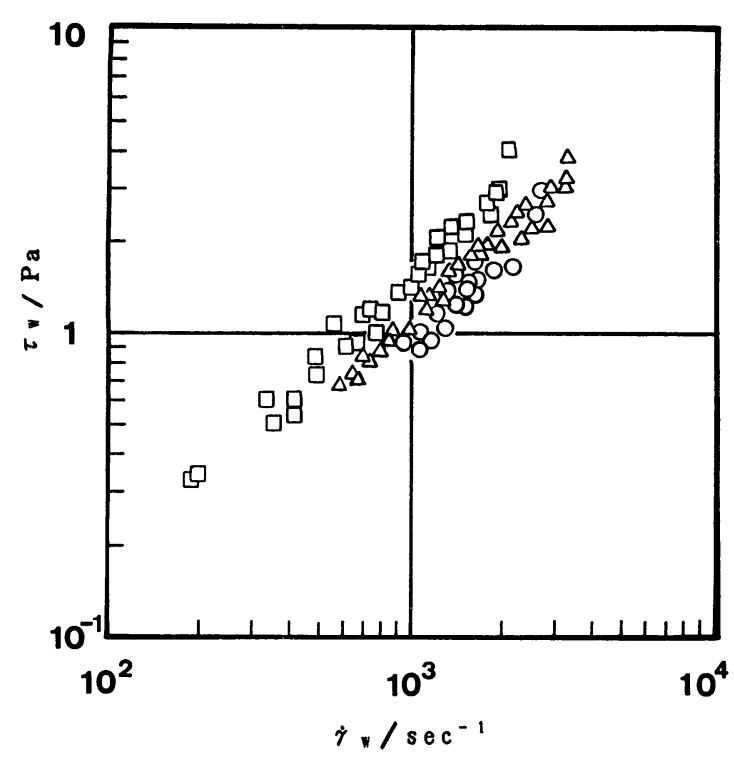

Fig. 8 Wall shear stress $\tau_{\mathrm{w}}$ versus wall shear rate $\dot{\gamma}_{\mathrm{w}}$. $\bigcirc$; water, $\triangle$; LAS $1.0 \%, \square$; PEO 20ppm

に出ず，ワイヤー抗力測定時のような複雑な流動場の場合に $C_{\mathrm{D}}$ 值の違いとして現れる可能性のあること，などが考学られる.)

この図からわかるように，各流体の実験值は傾さ 1.0 の直線に ほぼのって抢り，ニュートン粘性を示している. また，その絶対 值から, 粘度は希薄高分子溶液, 界面活性剤水溶液, 水の順に高 いことがわかる。

粘性のこの傾向を $C_{\mathrm{D}}$ と比較すると, $\mathrm{PEO}$ については粘度, $C_{\mathrm{D}}$ 共に水より高い。乙かし， LAS, $\mathrm{AE}$ では粘度は水より高い が $C_{\mathrm{D}}$ は水とほぼ同じか水より低い值をとっている．またさらに は，粘度は $C_{\mathrm{D}}$ を示す図の $R e_{\mathrm{w}}$ の中にすでに含まれている。 こ れらのことから, 各溶液の $C_{\mathrm{D}}$ の変化は粘度だけでは説明できず, 溶液の他の物性, 例穴ば弾性や分子間力などの点から検討する必 要があろう。また，ワイヤーや流路壁に高分子や界面活性㓮が吸 着していることも考兄られ，この点からの検討の余地も残されて いる.

このように, 水, 界面活性剤水溶液, 希薄高分子溶液は $C_{\mathrm{D}}$ に 関してそれぞれ異なる傾向を示す．これを実際の洗浄系から考え ると， $C_{\mathrm{D}}$ の高い希薄高分子溶液は, 流体力の面からは水より污 れ除去に有効であると解釈できる，従って，例えば市販洗㶡に高 分子物質を配合することで, 流体力を活用できる可能性があり, 界面活性剤の化学的作用とともに, より高い洗浄力の獲得が期待 できる。

\section{4. よ め}

洗浄機構に関る物理的作用を流体力の面から明らかにするため, 污れに関連した基本モデル装置を作成して，実験を行った。

すなわち，污れモデルを想定した微小円柱を壁面に付着させ， 水, 界面活性剂 (LAS, AE) 水溶液, 希薄高分子 (PEO) 水溶 液の層流せん断流を直角に当てることにより生ずる圧力損失を゙測 定し, 円柱一本の抗力係数 $\left(C_{\mathrm{D}}\right)$ を算出した.
得られた結果は以下の通りである。

1）すべての溶液で, 円柱の抗力はレイノルズ数とともに増加す るが， $C_{\mathrm{D}}$ はレイノルズ数と共に単調に減少する.

2）陰イオン系界面活性剤 LAS 水溶液は, 水よりも低い $C_{\mathrm{D}}$ 值 を示し，本実験範囲で濃度が高いほどこの傾向は顕著である。 非イオン系の $\mathrm{AE} 1.0 \%$ 水溶液は, 溶液作成後の経過時間が 1 日程度であると水に比べ $1 / 2$ 程度の低い $C_{\mathrm{D}}$ を示すが， 4 日程 度で水と同程度の $C_{\mathrm{D}}$ となる。

3）高分子 PEO の希薄水溶液は, 水, 界面活性剂水溶液よりも 高い $C_{\mathrm{D}}$ 值を示す。

4) 溶液の粘度は, PEO 希薄水溶液, LAS $1.0 \%$ 水溶液, 水の 順に高かったが，これは $C_{\mathrm{D}}$ の傾向とは一致していない。

本研究を行うにあたり, 適切なる御助言を賜りました新潟大学 工学部流体工学研究室の鳴海敬倫氏に厚く御礼申し上げます。ま た，実験に御協力いただいた堀川浩人氏，丸山英樹氏，関口弘恵 氏，渡邊美千代氏，千葉由美子氏，上野ミュキ氏に厚く御礼申し 上げます。

本論文の一部は，日本レオロジー学会第17年会（1990，千葉 市), 第22回 (1990, 東京) 叔よび第23回（1991，西宮市）洗浄 に関するシンポジゥムにて発表した.

\section{文献}

1）長谷川富市，多田千代，油化学，32，397（1983）

2）長谷川富市, 多田千代, 油化学, 34, 545 (1985)

3）長谷川富市, 鳴海敬倫, 近野正昭, 多田千代, 油化学, 36, 419 (1987)

4）岩崎芳枝, 小林明子, 原田弥生, 矢部章彦, 油化学, 29 , 495 (1980)

5）岩崎芳枝, 小林明子, 原田弥生, 矢部章彦, 油化学, 30, 232 (1981)

6) Iwasaki Y, Hikage Y, Yabe A, Text Res J, 56, 556 (1986)

7）岩崎芳枝, 日景弥生, 矢部章彦, 油化学, 36, 254 (1987)

8）岩崎芳枝, 矢部章彦, 油化学, 39, 654 (1990)

9）平松 峻，小谷昭子，絨維製品消費科学会誌， 22，149 (1981)

10）平松 峻，小谷昭子， 䋐維製品消費科学会誌， 22， 186 (1981)

11）平松 峻，小谷昭子，䋐維製品消費科学会誌， 23，31 (1982)

12）平松 峻，小谷昭子，絨維製品消費科学会誌， 25, 83 (1984)

13）白岩治已，金城学院大学論集， 24，1（1984）

14）白岩治巳，山田寿子，䋐維製品消費科学会誌，28，85 (1987)

15）白岩治巳，繊維製品消費科学会誌，32，542（1991）

16）柏 一郎, 平林 隆, 角田光雄, 大場洋一, 油化学, 20, 304 (1971) 